\title{
The Impact of Handbooks on the Concept Understanding and Learning Interests of Students on the Concept of Reaction Rate
}

\author{
Zulham Handayani $^{1}$, A. Halim ${ }^{1,2^{*}}$, Ibnu Khaldun ${ }^{3}$ \\ 1,Department of Science Education, Graduate School, Universitas Syiah Kuala, Banda Aceh, Indonesia \\ 2.Department of Physics Education, Teacher Training and Education Faculty, Universitas Syiah Kuala, Banda Aceh, Indonesia \\ 3.Department of Chemistry Education Teacher Training and Education Faculty, Universitas Syiah Kuala, Banda Aceh, Indonesia
}

\section{DOI: $10.29303 /$ jppipa.v7i2.628}

\section{Article Info}

Received :February 9th, 2021

Revised : April 14th, 2021

Accepted: April 18th, 2021

\begin{abstract}
This study aims to determine the impact of pocket books on conceptual understanding and student interest in learning. The research method used is quasi experimental using the nonequivalent control group design. The population in this study were students of class XI MIPA SMA Negeri 1 Jaya. The number of samples consisted of 60 people, each class consisting of 30 students. The research instruments used were test questions and questionnaires. The data analysis technique used the conceptual understanding through the $\mathrm{N}$-Gain test and the independent sample $\mathrm{t}$-test, while the interest in learning used the percentage formula. The results of the N-gain test for understanding the concept obtained that the average experimental class was higher than the control class, each class belonging to the criteria for moderate improvement. The results of the independent sample t-test showed that there was a significant difference between the students' conceptual understanding of the experimental class and the control class. The results of interest in learning from each subscale: family encouragement, teacher influence, and classroom learning experiences in the experimental class obtained a very high category. Meanwhile, on the subscale the peer attitudes toward chemistry and the informal learning experiences were high. For the control class, the category obtained on the family encouragement subscale is high, while the subscale for peer attitudes toward chemistry, teacher influence, informal learning experiences, and classroom learning experiences is in the moderate category. The average percentage of learning interest in the experimental class was obtained in the very high category, while the control class was in the medium category. The conclusion of this study is that the impact of using pocket books on chemistry learning can improve students' understanding of concepts and interest in learning.
\end{abstract}

Keywords: Pocket books, understanding concepts, interest in learning

Citation: Handayani, Z., Halim, A., \& Khaldun, I. (2021). The Impact of Handbooks on the Concept Understanding and Learning Interests of Students on the Concept of Reaction Rate. Jurnal Penelitian Pendidikan IPA, 7(2), $239-248$. doi:https://doi.org/10.29303/jppipa.v7i2.628

\section{Introduction}

The national curriculum, namely the 2013 curriculum, focuses on directing students to be actively and interactively involved in learning activities in order to stimulate critical thinking and improve the ability to understand lesson concepts well (Havwini, 2019). In learning in the 21st century, teachers are required to prepare students to have higher-order, critical, and creative thinking skills (Ramdoniati et al., 2019). In achieving this learning, it is necessary to have a basic understanding of the concepts of the subject properly (Setyowati et al., 2015). The nature of students' understanding of the concept of learning is one of the important components achieved in educational goals (Ozkan \& Topsakal, 2020). This is in accordance with the statement of Sulastri et al. (2018), the expected goals after 
students undergo the educational process are changes in behavior, attitudes, and understanding of the concept of material provided by the teacher.

Most students stated that the concepts contained in chemistry learning were quite complicated because they presented concepts using abstract symbols and terms that had to be memorized. The difficulty of learning chemistry is what can make students have a bad perception of learning chemistry (Sausan et al., 2019). This results in the attitudes and interests of students in learning chemistry to be low, so that the chemical values obtained tend to be lower than in other subject matter (Kubiatko et al., 2017). Students' low learning interest in the learning process as a result of application in learning is not in accordance with the mandate of the 2013 curriculum (Mulyani et al., 2020).

One of the chemical materials that students consider difficult is the rate of reaction material. Based on the results of the study, it shows that students' understanding at the level of submicroscopic representation in the material, the reaction rate is still low compared to other levels of chemical representations, namely macroscopic and symbolic (Handayanti et., 2015). Previous research results also showed that students had a limited understanding of concepts and reasoning abilities to explain the concept of chemical kinetics (rate of reaction) (Driel, 2002). The results of other studies, such as those reported by Habiddin and Page (2020), show that the ability of students to answer pictorial questions about reaction rate material is not good enough, so that it requires emphasis on images, graphs, tables and also submiscroscopic representations. Fostering interest and increasing good conceptual understanding are very important goals in learning chemistry (Hoft \& Bernholt, 2019).

Chemistry learning should not only introduce students to the abstract concepts involved in explaining reaction rates, but also ways that students can apply these concepts to various situations and contexts (Cakmakci et al., 2006). Contextual reaction rate learning can foster interest and motivation to learn because students are able to connect and apply the knowledge, they have in real life conditions (Ilyas \& Liu, 2020).

The results obtained in the Program for International Student Assessment (PISA) and Trends in International Mathematics and Science Study (TIMMS) show that Indonesia's ranking is relatively low compared to other countries. The 2018 PISA report on science subjects, Indonesia obtained an average score of 389, while the OECD average score was 489 (OECD, 2019). The results of the 2015 TIMMS report in the field of science, the score obtained by Indonesia is 397 . These results state that Indonesia is in 45th place out of 48 countries (IEA, 2016). The PISA and TIMMS reports show unsatisfactory results and Indonesia is still in the lower group and the average score is far below the world average score. This indicates that students in Indonesia have not mastered the concepts tested on PISA and TIMMS. This unpreparedness ultimately has an impact on students' low understanding of the concept of learning material. For this reason, efforts are needed to improve understanding of the concept of material in order to increase the quality of education in Indonesia (Oktariani \& Febliza, 2019). According to Raharjo (2014), if all national education standards can be met properly, it can contribute to increasing student learning achievement.

The success of learning achievement is determined not only by external factors, but also by internal factors such as motivation, interests, parental background, and the school environment (Raharjo, 2014). This research, besides focusing on external factors, namely learning resources in the form of teaching materials, also focuses on internal factors of interest in learning. Interest is an important factor and can provide positive energy in the learning process, so that it has an impact on learning achievement. Students who have high interest, then their psychological state always has attention and a tendency towards a certain topic or object so that it makes them always repeat these subjects (Harackiewicz et al., 2016). Students who have an interest in learning certain subjects, they will feel happy learning them. Interest in learning can be developed using various methods, one of which is by conditioning the learning atmosphere in the classroom. Interesting learning will generate interest in learning in deepening learning materials (Nursa'adah \& Rosa, 2016).

The high level of teacher understanding of the importance of choosing the right media in the learning process in the classroom is expected to contribute to increased understanding of concepts and interest in learning (Mulyana et al., 2013). One of the efforts made by the teacher to improve students' understanding of concepts and interest in learning can be done by using learning media in the form of teaching materials, namely pocket books. The advantages of pocket books that are developed as teaching materials in this study are their small size and can be carried by students anywhere when they want to study. The pocket book also contains concise, clear and complete concepts and is designed in such a way with a variety of images, letters and colors to attract students' interest in reading and studying it (Atsiah et al., 2020). In addition, this pocket book is designed to contain chemical concepts based on three levels of representation, namely macroscopic, submicroscopic, and symbolic. The picture presented in the pocket book also links the concept of material with real life conditions that have practical value. According to Nurjannah and Dwi (2019), the use of learning media 
is packaged creatively, innovatively, and attractively which can be used to achieve learning objectives.

The results of several previous studies show that the development of pocket books in the learning process received good responses with a value of $86 \%$ in the very good category (Cahyono et al., 2018). Lena et al., (2020) reported that the development of pocket books on chemistry subjects can increase student motivation and learning outcomes. On another occasion Zukmadini et al. (2020) reported the results of their research, namely that the pocket book developed received a good response by teachers and students, and was effectively used in increasing students' conceptual understanding.

Based on the background of the problem, the purpose of this study was to determine the impact of the pocket book on understanding the concepts and learning interests of students on the reaction rate material.

\section{Method}

The method used in this study is a quasiexperimental study using a quantitative approach with the aim of testing theories objectively by examining the relationship between variables (Creswell \& Creswell, 2018). The research design used the nonequivalent control-group design. This method is popular for quasiexperimental research designs, in which the experimental class and the control class are selected without randomizing them. Both groups did the pretest and posttest. Only the experimental group was given treatment (Creswell \& Creswell, 2018).

Table 1. Research Design

\begin{tabular}{llccc}
\hline No & Group & Pretest & Treatment & Posttest \\
\hline 1 & Eksperiment & $\mathrm{O}_{1}$ & $\mathrm{X}$ & $\mathrm{O}_{2}$ \\
2 & Control & $\mathrm{O}_{1}$ & & $\mathrm{O}_{2}$ \\
\hline \multicolumn{5}{c}{ (Source: Creswell \& Creswell, 2018) }
\end{tabular}

This research was conducted at SMA Negeri 1 Jaya in class XI MIPA students located on Jalan Teuku Umar, Lamno, Meunasah Weh, Jaya District, Aceh Jaya Regency. The total population consists of all students of class XI.MIPA SMA Negeri 1 Jaya. The research sample was class XI-MIPA1 and class XI.MIPA2, each of which consisted of 30 students. In this study, the experimental class was given learning material on reaction rates using additional teaching materials in the form of pocket books, while the control class used learning that was usually done by the teacher, namely only using textbooks. The pocket book used in the research is a development product that has gone through the needs analysis stage, validation by experts consisting of 3 lecturers and 1 chemistry teacher, and has gone through validity and reliability tests to see the valid aspects so that it can be used in the learning process.

Data collection techniques in this study were carried out by means of the test method and questionnaire. The research instrument consisted of multiple-choice questions that were reasoned to see the understanding of the concept and a questionnaire sheet to see the learning interests of students. Learning tools such as syllabus and lesson plan (RPP), the research instruments used have gone through the logical validation stage by experts. Furthermore, the test questions used have been subjected to empirical validation or trials and then analyzed, reviewed, and revised to get really good, valid, reliable, objective, and practical questions to use (Yusuf, 2015).

The results of the respondents' answers were then analyzed to determine the validity, reliability, difficulty index, differentiation power and distractor function. After that, questions that are valid, reliable, discriminatory power are accepted, the difficulty index is moderate to difficult, the trickster function properly is then taken to be given during the pretest and posttest to see students' understanding of the concept of the reaction rate material. A good test that meets the requirements can be started from the time of compiling the test, which is compiled based on the subject syllabus, making a grid first, and arranging questions according to the rules for arranging questions based on the type or shape of the questions (Kadir, 2015).

For the instrument of learning interest, it uses statement items that are valid and reliable in measuring students' interest in learning. This is known based on the measurement results obtained by Lamb et al. (2012), used the Rasch model and analyzed using the Item Response Theory (IRT) and Classical Test Theory (CTT). Relevance analysis through logical validity shows that $56.25 \%$ of items are proven to have a strong relevance to learning interest assessed by expert experts. Reliability is obtained through statistical tests of internal reliability by obtaining high internal consistency (Cronbach's alpha) and adequate when reviewed $(\alpha=0.72)$. There are 18 statements that are valid and reliable in measuring interest in learning based on the results of these measurements. The statement items are included in 5 subscales, family encouragement, peer attitudes toward chemistry, teacher influence, informal learning experiences, and classroom learning experiences. Of the 5 subscales, this is broken down into 18 statement items, each of which is 12 positive statements and 6 negative statements (modification Lamb et.al, 2012). An interest in learning questionnaire consisting of four answer criteria, namely: strongly agree (SA), agree (A), disagree (D), and strongly disagree (SD).

Data analysis techniques to determine the increase in students' conceptual understanding using 
the N-Gain test. Analysis of the N-Gain test data using the formula and criteria for the Gain index (Meltzer, 2002). The interpretation of the N-Gain effectiveness data used the effectiveness interpretation category according to Hake (1999). Furthermore, a hypothesis test was carried out to see whether there was a significant difference between the experimental class and the control class starting with the normality test, homogeneity, and hypothesis testing using the $t$ test (independent sample t-test). For data on the results of the questionnaire on learning interest per subscale using the percentage formula.

Collecting research data begins with a need's analysis, compiling learning tools (syllabus, lesson program plans), pocket books, question instruments and questionnaires. The learning activities carried out have been adjusted to the scheduling of the educational units listed in the semester program. Learning is carried out in accordance with the activities arranged in the learning program plan which consists of 4 meetings with 1 meeting consisting of 2 lesson hours. The learning activities applied to the experimental class were through the discovery learning model using additional pocket book teaching materials, while the control class through the cooperative learning model only used textbooks.

The learning process in the preliminary activities begins with the implementation of the pretest in the experimental class and the control class. After that, in the experimental class students were distributed pocket books. Students observe apperception and motivation presented in pocket books. The next activity is to provide stimulation or stimulation related to the reaction rate material, then the next step is to identify the problem by asking questions related to stimulation about the reaction rate material. In the core activity, namely collecting and processing data by completing practice questions in the pocket book by studying the teaching material in the pocket book. The next stage is proof, where students reconcile the results of their answers with teaching materials in pocket books and other sources. In the closing activity, students are directed to take conclusions related to learning reaction rate material. In this activity, students are given a posttest and a questionnaire on their interest in learning.

\section{Result and Discussion}

\section{Students' Concept Understanding}

The students' understanding of the concept of SMA Negeri 1 Jaya on the material of reaction rate is measured through question indicators based on material sub-concepts. Wiyarsi et al. (2019), the reaction rate material consists of several topics such as the concept of chemical reactions, collision theory, factors affecting reaction rates, reaction rate equations and reaction order. Based on this topic, the conceptual understanding of the reaction rate material is summarized and divided into three sub-concepts, namely the concept of reaction rate, factors that influence reaction rates, and collision theory and activation energy. Based on the research results obtained, it is known that the level of understanding of the concept of students in the subconcept, namely the concept of reaction rate, factors that affect the rate of reaction, collision theory and activation energy has increased. The recapitulation of the average pretest, posttest, and N-Gain values per sub-concept obtained the following results as in Table 2.

Table 2. Analysis of Concept Understanding per Sub-concept

\begin{tabular}{|c|c|c|c|c|c|c|c|}
\hline \multirow{2}{*}{ No } & \multirow{2}{*}{ Sub-concept } & \multicolumn{3}{|c|}{ Experiment Class } & \multicolumn{3}{|c|}{ Control Class } \\
\hline & & Pretest & Postest & N-Gain & Pretest & Postest & N-Gain \\
\hline 1 & Concept reaction rate & 30,91 & 81,52 & 0,73 & 18,50 & 44,00 & 0,31 \\
\hline 2 & Influencing factors reaction rate & 42,00 & 87,33 & 0,78 & 28,33 & 61,33 & 0,42 \\
\hline 3 & Collision theory and energy activation & 42,55 & 87,50 & 0,77 & 30,00 & 60,83 & 0,41 \\
\hline
\end{tabular}

Based on Table 2, the concept of the reaction rate is measured using question numbers $1,2,3,4,5,6,7,8$, 9,10 , and 11 which are arranged based on question indicators through the formulation of indicators of competency attainment (ICA) on reaction rate material . The N-Gain acquisition in the experimental class reaction rate concept was 0.73 with a high increase category or a fairly effective percentage increase of $73.12 \%$. Whereas in the control class, it was obtained 0.69 with the criteria for moderate improvement or a percentage of $69.34 \%$ which was quite effective. The difference between the experimental class and the control class was not far enough, so that the concept of reaction rate in both classes experienced an increase in $\mathrm{N}$-Gain in the moderate or quite effective category. Students in the control class who learn using textbooks tend to memorize formulas and rely on numeracy skills.

Indicators in this sub-concept include: describing the rate of the reaction, the value of the reaction rate, equations and rate constants, and the order of the reaction. Andromeda et al. (2018) explained that the material of chemical kinetics or reaction rate not only requires students to memorize formulas and calculate, but also hopefully understand the concepts of reaction rates abstractly or based on the level of submicroscopic representation. Another study on the reaction rate 
material which stated that the experimental class and the control class were not much different were also reported by Zuriatni et al. (2019). The results showed that the difference in N-Gain cognitive learning outcomes between the experimental class and the control class obtained a very small percentage of 0.7 . The two classes obtained N-Gain results which were not much different, which means that they were in the high category.

In the sub-concept, the factors that affect the rate of reaction are measured using question numbers 12,13 , 14,15 , and 20 . The N-Gain of the experimental class was 0.78 with a high increase category or the percentage of increase was quite effective, namely $77.94 \%$. Whereas in the control class it was obtained 0.42 with the criteria for moderate improvement or $41.78 \%$ percentage less effective. The experimental class applies pocketbook learning which has a better impact than ordinary textbooks on understanding the sub-concept of the factors that affect the reaction rate. The pocket book presents pictorial chemistry concepts by showing three levels of representation, namely, macroscopic, submicroscopic, and symbolic.

The results of research by Doyan et al. (2018) states that a learning approach that uses multiple representations has a positive impact on improving learning outcomes and student motivation. Meutia et al (2021) reported that multi-representation learning developed on the factors that affect the rate of reaction fulfills the very feasible criteria and can be used to improve students' completeness understanding of concepts very well. Ahiakwo and Isiguzo (2015), about $90 \%$ of students who tend to experience misconceptions related to sub-concepts of factors that affect the rate of reaction, so it needs to be discussed further to find a solution. Habiddin and Page (2020) reported that students experienced misconceptions on the temperature factor and assumed that an increase in temperature could increase the activation energy, resulting in an increase in the reaction rate. Umam et al. (2015) also reported the results of their research, namely students did not understand the reasons why increased concentration could increase the reaction rate. Students tend to be unable to make a connection between the concept of kinetic energy, collision theory, and reaction rate.

The next sub-concept is the collision theory and activation energy which is measured using test questions from numbers $16,17,18$, and 19 . The results of the $\mathrm{N}$-Gain test for the experimental class of 0.77 belong to the category of high increase and the percentage of increase in $77.22 \%$ is effective. While the control class obtained N-Gain value 0.41 with the medium category or the percentage increase in 41.11, which is less effective. In the experimental class, students learn by using pocket books which have a good impact in increasing understanding of the sub-concepts of collision theory and activation energy. In this pocket book, he explains the concept of collision theory and activation energy through an analogy approach. In addition, the material on the reaction rate in the pocket book is accompanied by pictures and examples related to everyday life, so that students are happy and quickly understand the sub-concept of collision theory and activation energy. Tsegaye et al. (2020) stated that the reaction rate material could be well understood by students if taught and instructed using the analogy approach compared to the traditional approach, meaning that it was monotonous and relatively fixed in every learning activity.

The result of understanding the chemical concept of the material reaction rate as a whole obtained that there was an increase in each sub-concept under study in the material reaction rate. The percentage obtained for each concept is different. The percentage comparison and N-Gain in each experimental and control class is shown in Table 3.

Table 3. Results of the Analysis of the Understanding of Chemical Concepts

\begin{tabular}{llcccccc}
\hline \multirow{2}{*}{ Voriables } & \multicolumn{2}{c}{ Pretest } & \multicolumn{2}{c}{ Posttest } & \multicolumn{2}{c}{ N-Gain } \\
\cline { 3 - 7 } & & Experiment & Control & Experiment & Control & Experiment & Control Criteria \\
\hline 1 & Total & 1075 & 960 & 2323 & 2145 & 22.63 & 17.39 \\
2 & Means & 35.83 & 32.00 & 84.17 & 71.50 & 0.67 & 0.51 \\
3 & SD & 8.103 & 7.26 & 6.706 & 9.02 & & \\
4 & Varians & 65.66 & 52.76 & 44.97 & 81.29 & & \\
\hline
\end{tabular}

Table 3 shows that the pretest and posttest data on the understanding of the chemical concept of students in class XI MIPA 1 (experimental class) at SMA Negeri 1 Jaya on the matter of the reaction rate increased with the average acquisition before 35.83 and after learning using a pocket book became 84.17 . The N-Gain result of the experimental class was higher than the N-Gain value of the control class. The N-Gain value of the experimental class was obtained 0.67 with moderate criteria and the percentage of improvement was 66.55 which was 
categorized as quite effective. In class XI MIPA 2 (control class) the N-Gain value was obtained 0.51 with an increase in percentage of 51.14 in the less effective category. If the N-Gain value obtained is greater than 0.3 and smaller than 0.7 , it is considered a moderate increase criterion (Meltzer, 2002).

Based on the N-Gain percentage range obtained in the experimental class, which is between $56-75 \%$, it is declared quite effective, while the control class between the gains of $40-55 \%$ can be declared less effective and less than 40 is declared ineffective (Hake, 1999). This is in accordance with the results of the research of Maulidah and Wulandari (2021), which states that the results of the pretest between the experimental class and the control class show a low understanding of concepts, after the application of learning media in the experimental class, the posttest results show a significant increase in concept understanding. The results of research by Mardiah et al. (2016) stated that teaching materials that meet the criteria of validity and effectiveness can be used to support the learning process to increase interest and make it easier for students to achieve learning objectives. Ramdoniati et al. (2019) adding teaching materials for its systematic arrangement can make it easier for students to learn.

Analysis of statistical test data is used to see differences in understanding the concept of the experimental class and the control class. Data analysis using SPSS version 21, the first stage by conducting descriptive analysis and normality test with Kolmogorov-Sminov and Shapiro-Wilk in each experimental class and control class for the pretest and posttest values obtained Sig.> 0.05 , which means the data is normally distributed. After that, a paired sample t-test was carried out to see the average difference in concept understanding in each class before and after learning using pocket books and textbooks.

The results obtained by the paired sample t-test between the experimental class and the control class concluded that there was a difference between before and after learning both with pocket books and textbooks. The next statistical test is to perform the homegeneity test with the mean value of $0.059>0.05$, which means that the posttest data for the experimental class and control class are the same or homogeneous. The last statistical test was carried out by using the independent samples t-test. The results obtained show the value of Sig. (2-tailed) of $0.000<0.05$ and the posttest $t$ test obtained tcount $>$ ttable with a value of 6.174> 2.021 , so it was concluded that the use of pocket books in learning chemistry reaction rates was more effective in improving students' understanding of concepts compared to ordinary textbooks. In line with the research results of Zukmadini et al. (2020) reported the results of their research, namely the pocket book developed was effectively used in increasing students' conceptual understanding. Susilaningsih et al. (2019) explain that teaching materials are one of the supporting facilities in achieving learning success. Several other research results indicate that concept understanding can also be improved by using discovery learning-based LKPD (Junina et al., 2020), and using a multirepresentative approach to the concept of straight motion (Hasbullah et al., 2018).

\section{Students' Learning Interests}

The questionnaire contains statements about learning to obtain information on students' learning interests (Mulyani et al, 2020). The interest in learning questionnaire was given after the students of SMA Negeri 1 Jaya learned the reaction rate material, namely the experimental class and the control class. The questionnaire given consisted of 18 statements divided into five subscales, namely: family encouragement, peer attitudes toward chemistry, teacher influence, informal learning experiences, and classroom learning experiences. The questionnaire was given to see whether there was an increase in students' interest in learning. Interest questionnaire data can be seen in Figure 1.

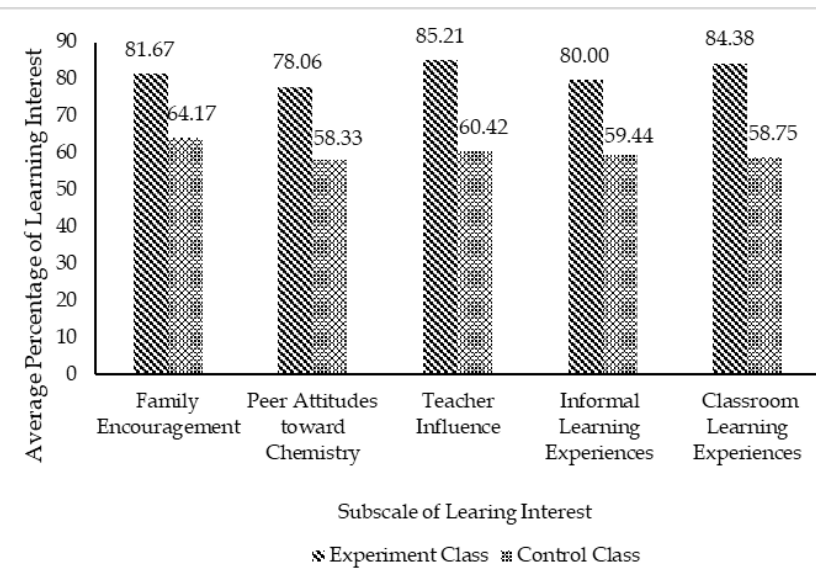

Figure 1. Results of the Study Interest Questionnaire per Subscale

Figure 1 shows that students' interest in learning has increased in the experimental class by learning chemistry using pocket books compared to the learning control class. The average percentage in the experimental class was $82.18 \%$ in the very high category, while the control class was $60.37 \%$ in the moderate category. The results of research conducted by Prihatini (2017) show that there is a significant influence between the use of learning media on learning outcomes and there is a significant influence between interest in learning-on-learning outcomes. The results of other studies reported by Astalini et al. (2019) is the statement of interest in increasing the time to study science 
dominantly has a good category, while the indicator of career interest in science is in a fairly good category.

Asyhari and Silvia (2016) added that learning media in the form of pocket books can be used as learning support media because students understand the learning material more easily because it contains concepts that are presented in an attractive, interactive, encouraging critical, creative, and innovative thinking. Increased interest can also be increased with smartphone media (Suwa et al., 2020). Besides that, interest also has a strong link with the achievements of students and the grade point average of students (Herliana et al., 2018).

Schools can provide learning as attractive as possible to activate cognitive learning opportunities, so as to increase the relationship between student interest and conceptual understanding (Hoft \& Bernholt, 2019). Students' interest in lessons can be seen from the tendency to pay greater attention to these lessons. If students have a great interest in learning, the value of their learning outcomes tends to change for the better (Prihatini, 2017). Wahyu et al. (2020) added that there have been many studies which state that the use of learning media can change the learning paradigm, namely improving learning processes and outcomes and can motivate students' learning. Based on the research, it can be concluded that interest has a significant effect on students' conceptual understanding. Besides learning media in the form of pocket book teaching materials applied in this study, interest in learning can also be increased through the use of Shit media (Mahzum et al., 2020), with the Science Technology Society (STS) (Maidan, et al, 2020), and media. tracker (Wati et al, 2020).

\section{Conclusion}

The conclusion in this study is: the use of pocket books on students of SMA Negeri 1 Jaya can improve understanding of the concept of the experimental class with the acquisition of N-Gain 0.67 in the moderate category. The results of the students' interest in learning at SMA Negeri 1 Jaya in the experimental class on the subscale of family encouragement, teacher influence, and classroom learning experiences obtained a very high category. On the subscale of peer attitudes toward chemistry and informal learning experiences, the high category was obtained. In the control class the category obtained on the family encouragement subscale was high, while the subscale of peer attitudes toward chemistry, teacher influence, informal learning experiences, and classroom learning experiences was obtained in the moderate category. Based on the five subscales, the overall average percentage of the experimental class learning interest is in the very high category of $82.18 \%$, while the control class is in the moderate category at $60.37 \%$.

\section{Acknowledgements}

Acknowledgments are addressed to all parties, namely validators, facilitator teachers and others who have contributed to this research. Furthermore, class XI MIPA students at SMA Negeri 1 Jaya and students at SMA Negeri 1 Calang, Aceh Jaya who have collaborated to become objects in this research

\section{References}

Andromeda, A., Ellizar, E., Iryani, I., Bayharti, B., \& Yulmasari, Y. (2018). Validitas dan praktikalitas modul laju reaksi terintegrasi eksperimen. JEP (Jurnal Eksakta Pendidikan), 2(2):132-139. doi: https://doi.org/10.24036/jep/vol2-iss2/250 [Indonesian]

Astalini, A., Kurniawan, D.A., Putri, D.A.D., \& Nawangsih, R. (2019). Identify student's attitude towards the subject of natural science. Journal of Education and Learning, 13(3):386-389. doi: http://dx.doi.org/10.11591/edulearn.v13i3.13144

Asyhari, A. \& Silvia, H. (2016). Pengembangan media pembelajaran berupa buletin dalam bentuk buku saku untuk pembelajaran IPA terpadu. Jurnal Ilmiah Pendidikan Fisika Al- Biruni, 5(1):1-13. doi: https://doi.org/10.24042/jpifalbiruni.v5i1.100 [Indonesian]

Atsiah, N.S.N., Ermawati, I.R., \& Laksanawati, W.D. (2020). Development of learning media in the form of value based physic pocket book. Omega: Jurnal Fisika dan Pendidikan Fisika, 6(1):20-26. doi: https://doi.org/10.22236/omega.v6i1.5003

Cahyono, B., Tsani, D.F., \& Rahma, A. 2018. Pengembangan buku saku matematika berbasis karalter pada materi trigonometri. Phenomenon: Jurnal Pendidikan MIPA, 8(2):185-199. [Indonesian]

Cakmakci, G., Leach, J., \& Donelly. (2006). Students' ideas about reaction rate its relationship with concentration or pressure. International Journal of Science Education, 28(15):1795-1815. doi: https://doi.org/10.1080/09500690600823490

Creswell, J.W. \& Creswell, J.D. (2018). Research Design :Qualitative, Quantitative, and Mixed Methods Approaches Fifth Edition. United States of America: Sage Publications.

Doyan, A., Taufik, M., \& Anjani, R. 2018. Pengaruh pendekatan multi representasi terhadap hasil belajar fisika ditinjau dari motivasi belajar peserta didik. Jurnal Penelitian Pendidikan IPA (JPPIPA), 4(1):35-45.

doi: 
https://doi.org/10.29303/ippipa.v4i1.99 [Indonesian]

Driel, J.H.V. (2002). Students' corpuscular conceptions in the context of chemical equilibrium and chemical kinetics. Chemistry Education: Research and Practice in Europe, 3(2):201-213. doi: https://doi.org/10.1039/B2RP90016E

Habiddin \& Page, E.M. (2019). Development and Validation of a Four-Tier Diagnostic Instrument for Chemical Kinetics (FTDICK). Indonesian Journal of Chemistry (e-Journal), 19(3):720-736. doi: https://doi.org/10.22146/ijc.39218

Hake, R.R. (1999). Analyzing Change/Gain Scores. Diakses dari laman web tanggal 19 Juni 2016 dari: http://www. physics. indiana. edu/ sdi/AnalyzingChange-Gain. Pdf.

Handayanti, Y., Setiabudi. A., \& Nahadi. (2015). Analisis profil model menta siswa SMA pada materi laju reaksi. Jurnal Penelitian dan Pembelajaran IPA, 1(1):107-122.

http://dx.doi.org/10.30870/jppi.v1i1.329

[Indonesian]

Harackiewicz, J.M., Smith, J.L., \& Priniski, S.J. (2016). Interest matters: the importance of promoting interest in education. Policy Insights from the Behavioral and Brain Sciences, 3(2):220-227. doi: https://doi.org/10.1177/2372732216655542

Hasbullah, H., Halim, A., \& Yusrizal, Y. (2018). Penerapan pendekatan multi Representasi terhadap pemahaman konsep gerak lurus. Jurnal IPA dan pembelajaran IPA, 2(2):69-74. https://doi.org/10.24815/jipi.v2i2.11621 [Indonesian]

Havwini, T. (2019). Indonesian EFL students willingness to communicate in the 2013 curriculum implementation: A case study. TEFLIN Journal, 30(1):105-120.

doi:

http://dx.doi.org/10.15639/teflinjournal.v30i1/1 05-120

Herliana, Mustafa, Halim, A., \& Daud, B. (2018). Correlation of Interest to be a teacher toward the Grade point average (GPA) of students physics education Department at Faculty of Teacher and Training Education, Syiah Kuala University (USK). International Proceeding at UUM Malysia Slangor, 17.

Hoft, L. \& Bernholt, S. (2019). Longitudinal couplings between interest and conceptual undersanding in school chemistry: an activity based perspective. International Journal of Science Education, 41(5):607627.

doi: https://doi.org/10.1080/09500693.2019.1571650

IEA. (2016). TIMSS 2015 International Results in Science, Ina V.S. Mullis, Michael O. Martin, Pierre Foy, and Martin Hooper, http://timss2015.org/.
Ilyas \& Liu, A.A. (2020). The effect of based e-learing contextual approach on student learning motivation. Jurnal Penelitian Pendidikan IPA (JPPIPA), 6(2):184-189. doi: https://doi.org/10.29303/ippipa.v6i2.425

Junina, I., Halim, A., \& Mahidin. (2020). The effect of discovery learning-based worksheet on students ' metacognition skill and learning outcomes. Journal of Physics: Conference Series, 1460(0122100): 1-9.

Kadir, A. (2015). Menyusun dan menganalis tes hasil Belajar. Al-Ta'dib: Jurnal Kajian Ilmu Pendidikan, 8(2):70-81.

doi:

http://dx.doi.org/10.31332/atdb.v8i2.411

[Indonesian]

Kubiatko, M., Balatova, K., Fancovicova, J., \& Prokop, P. (2017). Pupils' attitudes toward chemistry in two types of czech schools. EURASIA Journal of Mathematics Science and Technology Education, 13(6):2539-2552. doi: https://doi.org/10.12973/eurasia.2017.01239a

Lamb, R.L., Anetta, L., Meldrum, J., \& Vallet, D. (2012). Measuring sciences interest: rasch validation of the science interest survey. Interational Journal of Science and Mathematics Education, 10:643-668. doi: https://doi.org/10.1007/s10763-011-9314-z

Lena, N.R., Nurmaliah, C., dan Mahidin, M. (2020). Development of pocket book on electron configuration materials to increase student motivation and learning outcomes. Journal of Physics: Conference Series, 1460(012101):1-9.

Mahzum, E., Farhan, A., \& Ramadhani, E. (2020). The use of social media instagram as instructional media for physics toward student's learning motivation. Asian Journal of Science Education, 2(1), 48-55.

doi:

https://doi.org/10.24815/ajse.v2i1.14997

Maidan, Halim, A., Safitri, R., \& Nurfadilla, E. (2020). Impact of problem-based learning (PBL) model through science technology society (STS) approach on students' interest. Journal of Physics: Conference Series, 1460(012145), 1-7.

Mardiah, A., Suwignyo, H., \& Kuswandi, D. (2016). Pengebangan modul membaca intensif materi cerita petualangan berbasis saintifik. Jurnal Pendidikan: Teori, penelitian, dan Pengembangan, 1(6):1115-1119.

doi:

http://dx.doi.org/10.17977/jp.v1i6.6455

[Indonesian]

Maulidah, N. \& Wulandari, F. (2021). Literature study: improving understanding of science concepts using science comics for elementary school students. Jurnal Penelitian Pendidikan IPA (JPPIPA), 7(1):80-86.

doi:

https://doi.org/10.29303/ippipa.v7i1.509 
Meltzer, D.E. (2002). The relationship between mathematics preparation and conceptual learning gains in physics: a possible "hidden variable" in diagnostic pretest scores. American Journal of Physics, $\quad 70(12): 1259-1268 . \quad$ doi: https://doi.org/10.1119/1.1514215

Meutia, F., Nurdin, \& Winarni, S. (2021). Development of e-student worksheets based on multiple representations of factors affecting reaction rates. Jurnal Penelitian Pendidikan IPA (JPPIPA), 7(2):129136. doi: https://doi.org/10.29303/ippipa.v7i2.533

Mulyana, A., Hidayat, S., \& Sholih. (2013). Hubungan antara persepsi, minat dan sikap siswa dengan ahsil belajar siswa dalam pembelajaran PKn. Jurnal Pendidikan dan Kebudayaan, 19(3):315-330. doi: https://doi.org/10.24832/jpnk.v19i3.291 [Indonesian]

Mulyani, Syafil, W., \& Firdaus, L.N. 2020. Improvement on student learning interest through the integrated sciences learning based on webbed model. Journal of Educational Science, 4(1):53-61. doi: http://dx.doi.org/10.31258/jes.4.1.p.53-61

Nurjannah \& Dwi, D.F. (2019). The implementation of pocketbook as development of learning media to improve students's motivation. Middle East Journal of Scientific Research, 27(6):508-510.

Nursa'adah, F.P. \& Rosa, N.M. (2016). Analisis kemampuan berpikir kreatif kimia ditinjau dari adversity quotient, sikap ilmiah dan minat belajar. Formatif: Jurnal Ilmiah Pendidikan MIPA, 6(3):197206. doi:

http://dx.doi.org/10.30998/formatif.v6i3.992 [Indonesian]

OECD. (2019). PISA 2018 Results (Volume I): What Students Know and Can Do, PISA, OECD Publishing, https://doi.org/10.1787/5f07c754-en

Oktariani \& Febliza, A. (2019). Analysis of The Alignment Between Chemistry Content on TIMSS And Science-Chemistry Textbooks of Junior High School. Jurnal Pendidikan Indonesia, 8(1):123-132. DOI: $\quad$ http://dx.doi.org/10.23887/ipiundiksha.v8i1.16101

Ozkan, G. \& Topsakal, U.U. (2020). Determining student's conceptual understandings of physics concepts. International Journal of Education, 8(3):1-5. doi: https://doi.org/10.34293/education.v8i3.2908

Prihatini, E. (2017). Pengaruh metide pembelajaran dan minat belajar terhadap hasil belajar IPA. Formatif: Jurnal Ilmiah Pendidikan MIPA, 7(2):171-179. doi: http://dx.doi.org/10.30998/formatif.v7i2.1831 [Indonesian]
Raharjo, S.B. (2014). Kontribusi delapan standar nasional pendidikan terhadap pencapaian prestasi belajar. Jurnal Pendidikan dan Kebudayaan, 20(4):470-482. doi: $\quad$ https://doi.org/10.24832/jpnk.v20i4.160 [Indonesian]

Ramdoniati, N., Muntari, Hadisaputra, S. (2019). Pengembangan bahan ajar kimia berbasis problem based learning untuk meningkatkan keterampilan metakognisi. Jurnal Penelitian Pendidikan IPA (JPPIPA), 5(1):2733. doi: https://doi.org/10.29303/ippipa.v5i1.148 [Indonesian]

Sausan, I., Saputro, S., \& Indriyanti, N.Y. (2019). An integrated learning media in chemistry: how can it help teachers and students to create a good impression?. USEJ (Unnes Science Education Journal), 8(3):312-322.

Setyowati, B.E., Widiyatmoko, A., \& Sarwi. 2015. Efektivitas model pembelajaran jigsaw II berbantuan LKS untuk meningkatkan pemahaman konsep dan karakter siswa. Unnes Science Education Journal, 4(3):982-989. [Indonesian]

Sulastri, Nazar, M., \& Adiska, D.N. (2018). Pengembangan hand-out konsep larutan berintegrasi nilai religi untuk meningkatkan minat belajar siswa SMA pada pondok psantren terpadu. Jurnal Pendidikan Sains Indonesia (Indoenesian Journal of Science Eduation), 6(2):95-100. doi: https://doi.org/10.24815/jpsi.v6i2.12352 [Indonesian]

Susilaningsih, E., Lastri, L., Drastisianti, A., Kusuma, E., \& Alighiri, D. (2019). The analysis of concept mastery using redox teaching materials with multiple represantion and contextual teaching learning approach. Jurnal Pendidikan IPA Indonesia. 8(4):475-81.

doi:

https://doi.org/10.15294/jpii.v8i4.18072

Suwa, A. M., Halim, A., \& Zainuddin. (2020). The influence of using smartphone to interesting learning and GPA in students at physics education department. Asian Journal of Science Education, 2(1), 18-23.

doi: https://doi.org/10.24815/ajse.v2i1.14734

Tsegaye, Z., Temesgen, A., \& Bogale, Y. (2020). Effect of analogy approach on the concepts of rates of chemical reactions on students' achievement and attitude. African Journal of Chemical Education, 10(2):33-77.

Umam, Y.I., Iskandar, S.M., Budiasih, E. 2015. Analisis dampak kesalahan konsep laju reaksi terhadap kesalahan konsep kesetimbangan pada siswa SMA. Jurnal Pendidikan Sains (e-Journal), 3(2):68-73. doi: $\quad$ http://dx.doi.org/10.17977/jps.v3i2.7454 [Indonesian] 
Wahyu, Y., Edu, A.L., \& Nardi, M. (2020). Problematika pemanfaatan media pembelajaran IPA di Sekolah Dasar. Jurnal Penelitian Pendidikan IPA (JPPIPA), 6(1):107-112. doi: https://doi.org/10.29303/jppipa.v6i1.344 [Indonesian]

Wati, S., Halim, A., \& Mustafa. (2020). The impact of the media tracker on student critical thinking skills. Journal of Physics: Conference Series, 1460(012139), 16.

Wiyarsi, A., Fachriah, A.R., Supriadi, D., Damanhuri, M.I.B.N. (2019). A test of analytical thinking and chemical representation abilty on'rate of reaction' topic. Cakrawala Pendidikan, 38(2):228-242. doi: https://doi.org/10.21831/cp.v38i2.23062

Yusuf, M. (2015). Asesmen dan Evaluasi Pendidikan: Pilar Penyedia Informasi dan Kegiatan Pengendalian Mutu Pendidikan Edisi Pertama. Jakarta: Kencana.

Zukmadini, A.Y., Kasrina, Jumiarni, D., \& Rochman, S. (2020). Pocketbook based on local wisdom and its effectivity in improving students' knowledge on the utilization of traditional medicine plants. Biosfer: Jurnal Pendidikan Biologi, 13(1):59-74. doi: https://doi.org/10.21009/biosferjpb.v13n1.59-74

Zuriatni, Y., Budiasih, E., \& Sumari. (2019). Pengaruh model pembelajaran guided discovery dengan kontekstual terhadap hasil belajar kognitif. Jurnal Pendidikan: Teori, penelitian, dan Pengembangan, 4(6):747-752.

doi:

http://dx.doi.org/10.17977/iptpp.v4i6.12494.

[Indonesian] 